\title{
Impact of Inflation, Dollar Exchange Rate and Interest Rate on Red Meat Production in Turkey: Vector Autoregressive (VAR) Analysis
}

\author{
Şenol Çelik \\ Bingol University, Bingol, Turkey
}

\begin{abstract}
In this study, impact of inflation (WPI-Wholesale Price Index), exchange rate, and interest rate on the production of red meat in Turkey was examined using the vector autoregressive (VAR) model. The model consisting of variables of dollar exchange rate, inflation rate, interest rate, beef, buffalo meat, mutton, and goat meat production amounts has been estimated for the period from 1981 to 2014. It has been detected that there is a tie among the dollar exchange rate, inflation rate, interest rate, and the amount of red meat production in Turkey. In order to determine the direction of this relation, Granger causality test was conducted. A one-way causal relation has been observed between: the goat meat production and dollar exchange rate; the buffalo meat production and the mutton production; and the beef production and the mutton production. To interpret VAR model, the impulse response function and variance decomposition analysis was used. As a result of variance decomposition, it has been detected that explanatory power of changes in the variance of dollar exchange rate, inflation rate, and interest rate in goat meat production amount is more than explanatory power of changes in the variances of mutton, beef, and buffalo meat variables.
\end{abstract}

Keywords: vector autoregressive (VAR) model, impulse response analysis, variance decomposition, unit root test, causality, red meat

\section{Introduction}

Today, the rapidly growing population and diminishing natural resources together are increasing the importance of adequate and balanced nutrition day by day for the protection of community health and development. Production of staple food which are necessary in a healthy diet of individuals in society is being either plant based or of animal origin necessitates the creation and development of agricultural policies that would allow effectively functioning of agricultural markets and opening the way for individuals to reach staple food at desired level and with minimum cost (Ünlüsoy, İnce, \& Güler, 2010).

In Turkey, animal husbandry constitutes the sub-sector of agricultural industry with the highest total output of its agrarian economy. In Central Anatolia, Southeastern Anatolia Region, and rural areas of the West and in East Anatolia Region in particular, livestock is the basic subsistence activity in primary agricultural level

Şenol Çelik, assistant professor, Faculty of Agriculture, Zootechnics Branch at Department of Animal, Bingol University, Bingol, Turkey.

Correspondence concerning this article should be addressed to Şenol Çelik, Faculty of Agriculture, Zootechnics Branch at Department of Animal, Bingol University, Bingol, 12000 Turkey. E-mail: senolcelik@bingol.edu.tr. 
(Akkaya, 2015).

According to the United Nations Food and Agriculture Organization 2013 statistics, in the ranking of countries, Turkey was ranking 4th in mutton production, 11th in beef, 13th in goat meat, and 19th in buffalo meat production in the world (Retrieved from http://faostat3.fao.org/download/Q/QA/E). In light of this information, Turkey appears to be a very important country of the world in terms of red meat production.

In Turkey during 1989, speculating foreign capital inflows being encouraged and high interest rates that needed for attracting foreign capital have crushing effects on the production structures. During the period from 1990 to 1999, distanced from real investments rent-seeking type ventures adversely affected the country's economy, as higher interest rates did the same to the agriculture sector (Günaydın, 2006). In addition to other reasons, the low dollar exchange rate led to the emergence of a boom in animal agricultural market particularly in sheep \& goat farming (Albayrak, 2002). In this, incentive system that applied in the agricultural policy framework plays an important role. In 2001, while EU supporting the agriculture by 105.6 billion US dollar, Turkey has given the support of 6.3 billion for the same period. While the share agriculture received from EU budget is growing over the years, Turkey seems to be trending toward reduction of agricultural support until recently (Olhan, 2006). Fallen consumption, as a result of decline in production and the continuous increase of price, was caused by failure to resolve the problems encountered on red meat in Turkey (State Planning Organization, 2007).

It must be known how production amount of red meat which holds an important place in human nutrition as main food was affected by inflation, dollar exchange rate, and interest rate, because preparing plans and policies aimed to increase production of red meat based on inflation, dollar exchange rates, and interest rates, which are the main indicators of country's economy, is extremely important. Although there are studies carried out in other areas related to the statistical methods used in this study, there are limited number of studies on animal husbandry variables.

In this study, unlike other studies, using VAR method, the relationship between livestock production with some economic indicators is examined in terms of Turkey's economy.

The aim of this study is to investigate the effect of inflation, the dollar exchange rates, and interest rates on red meat production amount and determining the relation between them.

\section{Materials and Method}

\section{Materials}

In the study, all statistical data on red meat production as materials are obtained from Statistical Institute of Turkey (TÜIK) and the United Nations Food and Agriculture Organization. Additionally, the data of average annual percent change of Wholesale Price Index (WPI) published by the Ministry of Development have been used (Retrieved from http://www.kalkinma.gov.tr/Pages/EkonomikSosyalGostergeler.aspx). Dollar exchange rate value and the rediscount rate (\%) values (1981-2010) published by the Republic of Turkey Central Bank (TCMB) have been used (TCMB, 2015). The information belonging to the period after 2010 was obtained from Statistical Indicators 1923-2013 published by TÜİK (2014). Dollar exchange rate and interest rate information for 2014 is taken from the TCMB's web address and WPI (\%) is taken from the web site of http://www.alomaliye.com/2015/tufe-aralik-2014.htm. The amount of red meat produced annually consists of beef, buffalo meat, mutton, and goat meat. The study covers the period between the years 1981-2014. Variables of the data used in the study are shown as follows: 
- SE: beef production amount;

- ME: buffalo production amount;

- KOE: mutton production amount;

- KEE: goat production amount;

- DOLAR: dollar exchange rate;

- WPI: Wholesale Price Index inflation rate (\%);

- INTEREST: central bank rediscount rate (\%).

\section{Research Method}

In order to obtain a significant relation among the variables used in the statistical analysis, series must be stationary. Stationarity, in general, is constant mean, constant variance and covariance between two values of the series, not depending on time studied, but depending only on the difference between the two time values (Berber \& Artan, 2004).

\section{Unit Root Test}

The stationarity test to be performed before the series of causality is investigated. In testing to determine whether or not series is stationary, Augmented Dickey Fuller (ADF) test which was developed by Dickey and Fuller (1981) can be used. According to Dickey and Fuller (1981), it is considered that the average term of the error is to be zero, to a normal distribution, and to the constant variance; error term is to be the white noise. The average of a stationary time series, variance, and covariance is not changing over time (Darnell, 1994). This test can be written in three different forms (Asteriou \& Hall, 2007).

$$
\begin{gathered}
D X_{t}=g X_{t-1}+\sum_{i=1}^{k} b_{i} D X_{t-i}+e_{t} \\
\Delta X_{t}=\alpha_{0}+g X_{t-1}+\sum_{i=1}^{k} b_{i} \Delta X_{t-i}+e_{t} \\
\Delta X_{t}=\alpha_{0}+\alpha_{1} t+\gamma X_{t-1}+\sum_{i=1}^{k} \beta_{i} \Delta X_{t-i}+e_{t}
\end{gathered}
$$

$\mathrm{ADF}$ test, in above equation, tests if $\gamma$ coefficient statistically is equal to zero. The results reached with $\mathrm{ADF}$ test can be compared to McKinnon critical values at significance level of $1 \%, 5 \%$, and $10 \%$. In the equation, $\Delta X_{t}$ shows the first difference of time series which is being analyzed to determine whether or not it is stationary, $t$ general trend variable and $\Delta X_{t-1}$ lagging difference terms.

\section{Vector Autoregressive (VAR) Model}

VAR model was developed by Sims (1980). In this method, dependence structure between the variables is not required. In this case, the variables in the model without the distinction among endogenous-exogenous all variables are considered endogenous. This feature provides flexibility in the analysis phase. In this method, each variable is projected by its own lagged values and the lagged values of other variables (Kadilar, 2000).

VAR models are being used primarily to examine the relations between macro economic variables and variables used in the analysis of the dynamic effects of random shocks on variables system. Moreover, according to many economists, unrestricted VAR gives better results than classical structural modeling for forecasting (Greene, 1993). First degree vector autoregression (VAR (1)) model is

$$
X_{t}=\alpha+\Phi X_{t-1}+e_{t}
$$


where, $\alpha$ is stationary; $\Phi$ is over $X_{t-1}$ with $k \times k$ dimension transition matrix of expression free from $X_{t}$ (Shumway $\&$ Stoffer, 2006); and $e_{t}$ is zero mean, with multivariate normal distribution, with zero covariance and stationary variances that are with white noise. Similarly VAR $(p)$ model is as follows (Akdi, 2010):

$$
X_{t}=\Phi_{1} X_{t-1}+\Phi_{2} X_{t-2}+\ldots+\Phi_{p} X_{t-p}+e_{t}
$$

VAR models often preferred for time series for that its dynamic relations can be given without limitation on the structural model (Keating, 1990). Additionally in VAR models, inclusion of the lagged values of the dependent variables allows making strong predictions for the future (Kumar, Robert, \& John, 1995). Such modeling methods are used for analyzing the dynamic structure of the time series (Stock \& Watson, 2001). Each variable used in the model is a function of past values of itself and other variables. When this function is used obtained with series of research by VAR model, it is expressed as follows:

$$
\left[\begin{array}{l}
\mathrm{SE} \\
\mathrm{ME} \\
\mathrm{KOE} \\
\mathrm{KEE} \\
\mathrm{DOLAR} \\
\mathrm{INTEREST} \\
\mathrm{WPI}
\end{array}\right]=\left[\begin{array}{l}
\alpha_{1} \\
\alpha_{2} \\
\alpha_{3} \\
\alpha_{4} \\
\alpha_{5} \\
\alpha_{6} \\
\alpha_{7}
\end{array}\right]+\left[\begin{array}{lllllll}
\Phi_{11}(\mathrm{~L}) & \Phi_{12}(\mathrm{~L}) & \Phi_{13}(\mathrm{~L}) & \Phi_{14}(\mathrm{~L}) & \Phi_{15}(\mathrm{~L}) & \Phi_{16}(\mathrm{~L}) & \Phi_{17}(\mathrm{~L}) \\
\Phi_{21}(\mathrm{~L}) & \Phi_{22}(\mathrm{~L}) & \Phi_{23}(\mathrm{~L}) & \Phi_{24}(\mathrm{~L}) & \Phi_{25}(\mathrm{~L}) & \Phi_{26}(\mathrm{~L}) & \Phi_{27}(\mathrm{~L}) \\
\Phi_{31}(\mathrm{~L}) & \Phi_{32}(\mathrm{~L}) & \Phi_{33}(\mathrm{~L}) & \Phi_{34}(\mathrm{~L}) & \Phi_{35}(\mathrm{~L}) & \Phi_{36}(\mathrm{~L}) & \Phi_{37}(\mathrm{~L}) \\
\Phi_{41}(\mathrm{~L}) & \Phi_{42}(\mathrm{~L}) & \Phi_{43}(\mathrm{~L}) & \Phi_{44}(\mathrm{~L}) & \Phi_{45}(\mathrm{~L}) & \Phi_{46}(\mathrm{~L}) & \Phi_{47}(\mathrm{~L}) \\
\Phi_{51}(\mathrm{~L}) & \Phi_{52}(\mathrm{~L}) & \Phi_{53}(\mathrm{~L}) & \Phi_{54}(\mathrm{~L}) & \Phi_{55}(\mathrm{~L}) & \Phi_{56}(\mathrm{~L}) & \Phi_{57}(\mathrm{~L}) \\
\Phi_{61}(\mathrm{~L}) & \Phi_{62}(\mathrm{~L}) & \Phi_{63}(\mathrm{~L}) & \Phi_{64}(\mathrm{~L}) & \Phi_{65}(\mathrm{~L}) & \Phi_{66}(\mathrm{~L}) & \Phi_{66}(\mathrm{~L}) \\
\Phi_{71}(\mathrm{~L}) & \Phi_{72}(\mathrm{~L}) & \Phi_{73}(\mathrm{~L}) & \Phi_{74}(\mathrm{~L}) & \Phi_{75}(\mathrm{~L}) & \Phi_{76}(\mathrm{~L}) & \Phi_{77}(\mathrm{~L})
\end{array}\right]\left[\begin{array}{l}
\operatorname{SE}_{t-1} \\
\operatorname{ME}_{t-1} \\
\operatorname{KOE}_{t-1} \\
\mathrm{KEE}_{t-1} \\
\operatorname{DOLAR}_{t-1} \\
\mathrm{INTEREST}_{t-1} \\
\mathrm{WPI}_{t-1}
\end{array}\right]+\left[\begin{array}{l}
e_{1 t} \\
e_{2 t} \\
e_{3 t} \\
e_{4 t} \\
e_{5 t} \\
e_{6 t} \\
e_{7 t}
\end{array}\right]
$$

where, $\alpha$ is stationary term; $e_{1 t}, e_{2 t}, \ldots, e_{7 t}$ mean zero and with stationary covariance random stochastic processes. In the term: $\Phi_{i j}(\mathrm{~L})$ in the matrix of coefficients, subscript $i j$ represents equation number and independent variable and $\mathrm{L}$ is lagging processor.

\section{Causality Test}

Causal relations among the variables are to be examined with Granger casuality test (1969). Based on these relations, Granger $(1969 ; 1980)$ and Sims $(1972)$ suggested casuality.

In VAR model to conduct casuality tests among variables, all variables required to be stationary (Enders, 1995). Granger casuality test is to be conducted with the equations (4) and (5) (Tar1, 2014).

$$
\begin{aligned}
& X_{t}=\beta_{0}+\sum_{i=1}^{n} \alpha_{i} Y_{t-i}+\sum_{i=1}^{n} \beta_{i} X_{t-i}+e_{1 t} \\
& Y_{t}=\alpha_{0}+\sum_{i=1}^{n} \beta_{i} X_{t-i}+\sum_{i=1}^{n} \alpha_{i} Y_{t-i}+e_{2 t}
\end{aligned}
$$

If the two time series are mutual causes, there would be a mutually causal relation (Granger \& Newbold, 1986). Models numbered (4) and (5) are established only on the lagged values, if the hypothesis $\beta_{i}=0$ is true, variable $X_{t}$ is not a granger reason for $Y_{t}$ (Maddala, 1989).

\section{Impulse and Response Functions}

Impulse response functions reflect the effect to the current and future value of endogenous variables of standard error shock in any of random error terms. Impulse response function is used to describe how a shock in one market (a one-standard-deviation shock) may propagate to others (Engle, Gallo, \& Velucchi, 2012).

\section{Variance Decomposition}

Variance decomposition is decomposition ratio of prediction error variance components of each variable 
that can be installed on each variable in the system (Pindyck \& Rubinfeld, 1991). Variance decomposition shows the percentage of the change that occurs in the used variable that originates from itself and the percentage from other variables.

If the large part of the changes occurring in the variable stems from the shock in itself, this is an exogenous acting of the variable. The variance decomposition provides information on the degree of causal relations among the variables (Enders, 1995). The variance decomposition provides information that determines the relative importance of each and every random shocks influence the variables in VAR (Nieh \& Yau, 2004).

\section{Findings}

Primarily stationarity analysis of variable series of red meat production, dollar exchange rate, interest rate, and WPI has been conducted. Therefore, ADF unit root test was calculated. As a result of unit root test conducted, series are found to be not significant at their level value. To make the series stationary, taking the first difference, the stationarity test was conducted again, according to Table 1 as a result of unit root test. When taking the first difference of the series SE, ME, KOE, KEE, DOLAR, WPI, and INTEREST, they were not with unit root. So it is stationary.

Table 1

Augmented Dickey-Fuller (ADF) Unit Root Tests

\begin{tabular}{lcl}
\hline Variables & Level & Row difference \\
\hline SE & -0.078 & $-6.974 * *$ \\
ME & -0.704 & $-5.862 * *$ \\
KOE & -2.120 & $-6.705^{* *}$ \\
KEE & -2.398 & $-6.509 * *$ \\
DOLAR & 0.619 & $-5.385^{* *}$ \\
WPI & -1.379 & $-9.719 * *$ \\
INTEREST & -0.399 & $-5.093 * *$ \\
\hline
\end{tabular}

Notes. Model için Mac Kinnon critical values for the model is 1\%, 5\%, and 10\% for significance level respectively $-3.662,-2.960$, and $-0.619 ; * * 1 \%$ significance level indicates stationarity of the variable.

The result of stationarity was supported by reverse roots of AR characteristic polynomial of predicted VAR model shown in Figure 1.

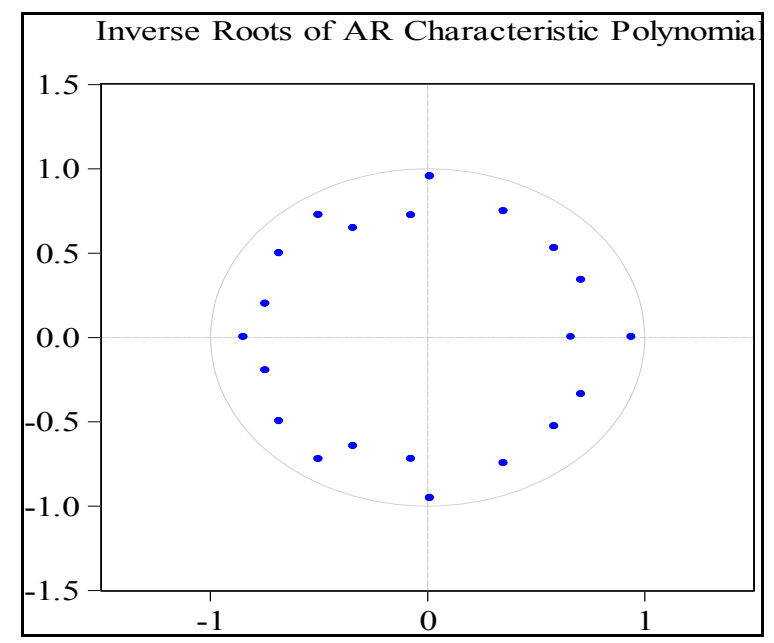

Figure 1. Stability of the integrity of the model. 
Table 2

Determining Criteria the Length of the Lag

\begin{tabular}{llllll}
\hline Lag & LR & FPE & AIC & SC & HQ \\
\hline 1 & 36.34443 & $8.22 e+46$ & 127.7981 & 130.4136 & 128.6348 \\
2 & 42.87071 & $2.25 e+47$ & 128.2067 & 133.1109 & 129.7756 \\
3 & 54.17176 & $5.78 e+46$ & $124.7019^{*}$ & 131.8947 & 127.0029 \\
\hline
\end{tabular}

Notes. Where LR is serially arranged LR test statistics; FPE is final prediction error; AIC is Akaike information criteria; SC is Schwarz information criteria; and HQ is Hannan-Quinn information criteria.

In Table 2 for the variables of SE, ME, KOE, KEE, DOLAR, WPI, and INTEREST, it was determined that appropriate length of delay was three according to AIC criteria. After determining appropriate length of delay, VAR analysis and Granger casuality test were conducted.

On the results of VAR analysis presented in Annex, goat meat production amount as being two delay has a relation between itself and buffalo meat production amount statistically significant $(P<0.05$ and $P<0.01)$. Goat meat production amount of two periods ago has impact on itself as much as -0.68 and on buffalo meat production -0.16 . Because the coefficients are negative, one unit goat meat production amount of two periods ago will cause decrease by 0.68 on itself and will cause decrease on buffalo meat production by 0.16 . Relation of goat meat production by three delay with beef production is statistically important $(P<0.05)$. One unit of goat meat production amount three periods ago will lead to an increase in beef production amount by 12.52 .

Buffalo meat production amount will lead to an increase, in goat meat production by 3.14 , in itself by 0.60 one period ago. Beef production amount will lead to an increase by 13.85 in mutton production amount as one unit three periods ago. Dollar exchange rate of three periods ago, as one unit will lead to a decrease in buffalo meat production amount by 0.05 unit. WPI values will lead to a decrease, as one unit in buffalo meat production by 2.75 units, one period ago. WPI values will lead to a decrease in buffalo meat production by 3.88 units, two periods ago. WPI values will lead to an increase in beef production amount by 2,441 units three periods ago.

According to Nazlığlu (2010), in the study of "Impacts of Macro Economic Policies on Agricultural Production; A Comparison for Advanced and Emerging Economies", effects of agricultural prices, money supply, government spending, inflation rate, interest rate, and exchange rate on agricultural production were analyzed with cointegration methods. The obtained results indicate that agricultural production is affected in a positive direction from the rise in agricultural prices and in exchange rate. According to Okumuş (2012), in the study of "Agricultural Policies and Time Series Analysis; An Application to Cotton Price in Turkey" cotton production, relation between the cotton price in the stock market and diesel fuel was analyzed with VAR method. Previous one year's production amount and cotton prices are found to be the important factors on production. With this aspect, the results obtained by this study differ from these results.

For three lag, results of $F$ tests which conducted to see whether or not there is a causality among the variables can be seen in Table 3. In line with these findings, goat meat production is caused by dollar exchange rate, in other words, there is a one-way causality relation from goat meat toward dollar exchange rate $(P<0.05)$ and there is a one-way causality relation also from buffalo meat toward mutton and from beef toward mutton $(P$ $<0.01)$.

Subaş1 and Ören (2013) have determined that from agricultural R\&D (research and development) spending toward agricultural growth, there is a one-way causality relation. This result contains different 
findings in comparison with the relation of inflation, dollar exchange rate, and interest rate to the red meat production in this study.

Table 3

Granger Causality Test Results

\begin{tabular}{|c|c|c|c|}
\hline Null hypothesis & $n$ & $F$-statistics & $P$ \\
\hline KOE does not Granger cause KEE & 30 & 0.84682 & 0.4824 \\
\hline KEE does not Granger cause KOE & & 0.18277 & 0.9070 \\
\hline ME does not Granger cause KEE & 30 & 0.11611 & 0.9498 \\
\hline KEE does not Granger cause ME & & 0.47821 & 0.7006 \\
\hline SE does not Granger cause KEE & 30 & 1.10344 & 0.3679 \\
\hline KEE does not Granger cause SE & & 1.56553 & 0.2248 \\
\hline DOLAR does not Granger cause KEE & 30 & 0.36285 & 0.7804 \\
\hline KEE does not Granger cause DOLAR & & 4.44639 & $0.0132 *$ \\
\hline INTEREST does not Granger cause KEE & 30 & 1.34721 & 0.2837 \\
\hline KEE does not Granger cause INTEREST & & 0.17704 & 0.9109 \\
\hline WPI does not Granger cause KEE & 30 & 0.69146 & 0.5666 \\
\hline KEE does not Granger cause WPI & & 0.02840 & 0.9934 \\
\hline ME does not Granger cause KOE & 30 & 5.19611 & $0.0069 * *$ \\
\hline KOE does not Granger cause ME & & 0.35075 & 0.7890 \\
\hline SE does not Granger cause KOE & 30 & 6.64778 & $0.0021 * *$ \\
\hline KOE does not Granger cause SE & & 1.21307 & 0.3273 \\
\hline DOLAR does not Granger cause KOE & 30 & 0.24962 & 0.8608 \\
\hline KOE does not Granger cause DOLAR & & 0.32200 & 0.8094 \\
\hline INTEREST does not Granger cause KOE & 30 & 0.63332 & 0.6010 \\
\hline KOE does not Granger cause INTEREST & & 0.07662 & 0.9720 \\
\hline WPI does not Granger cause KOE & 30 & 0.11926 & 0.9479 \\
\hline KOE does not Granger cause WPI & & 0.33849 & 0.7977 \\
\hline SE does not Granger cause ME & 30 & 0.35154 & 0.7884 \\
\hline ME does not Granger cause SE & & 0.38243 & 0.7666 \\
\hline DOLAR does not Granger cause ME & 30 & 0.19241 & 0.9005 \\
\hline ME does not Granger cause DOLAR & & 0.02213 & 0.9954 \\
\hline INTEREST does not Granger cause ME & 30 & 0.21191 & 0.8871 \\
\hline ME does not Granger cause INTEREST & & 0.25904 & 0.8541 \\
\hline WPI does not Granger cause ME & 30 & 2.26414 & 0.1080 \\
\hline ME does not Granger cause WPI & & 0.23140 & 0.8736 \\
\hline DOLAR does not Granger cause SE & 30 & 0.62720 & 0.6048 \\
\hline SE does not Granger cause DOLAR & & 0.71344 & 0.5540 \\
\hline INTEREST does not Granger cause SE & 30 & 0.34972 & 0.7897 \\
\hline SE does not Granger cause INTEREST & & 0.06472 & 0.9780 \\
\hline WPI does not Granger cause SE & 30 & 0.28900 & 0.8329 \\
\hline SE1 does not Granger cause WPI & & 0.03955 & 0.9892 \\
\hline INTEREST does not Granger cause DOLAR & 30 & 0.05635 & 0.9820 \\
\hline DOLAR does not Granger cause INTEREST & & 1.02188 & 0.4012 \\
\hline WPI does not Granger cause DOLAR & 30 & 0.34034 & 0.7964 \\
\hline DOLAR does not Granger cause WPI & & 1.22520 & 0.3231 \\
\hline WPI does not Granger cause INTEREST & 30 & 1.07402 & 0.3796 \\
\hline INTEREST does not Granger cause WPI & & 0.28767 & 0.8338 \\
\hline
\end{tabular}

Notes. $*$ is 0.05 and $* *$ is 0.01 significance level of materiality; 30 is the number of observations. 


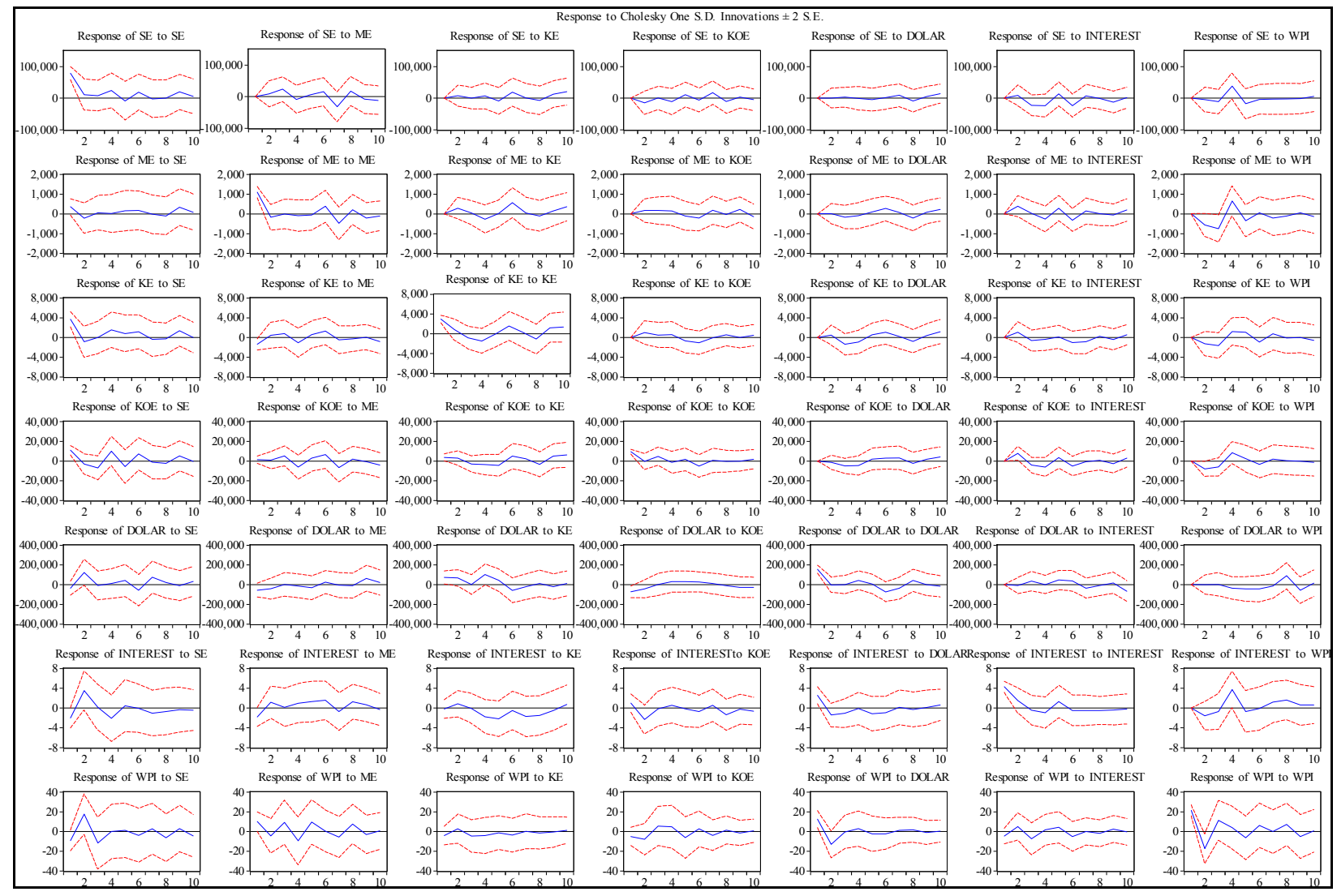

Figure 2. Impulse and response analysis results.

In Figure 2, it can be seen how dollar exchange rate, interest rate (\%), and WPI (\%) have effect on red meat. When a one-unit of shock is applied to change in the short-term monetary movements, for the purpose of dynamic effects to be seen as a result of other series (SE, ME, KOE, and KE), response to this change is given for 10 periods in Figure 2. Dashed lines on the graph indicate the confidence interval and straight lines show the point of estimate. The reaction of the beef production in the face of one unit shock in beef production in the first period is positive, in 5th period negative, and in following periods undulant positive. The reaction of the buffalo meat production in the face of one unit shock in buffalo meat production in first three periods is positive, 4th and 7th period negative, and in other periods positive. In the first period, the reaction of the goat meat production is positive in beef production in the face of one unit shock. It is negative in 5th period and positive in other periods. In the first period, the reaction of the mutton production is negative in the face of one unit shock in beef production, positive in 5th and 7th periods, and the reaction negative in other periods. In the face of one unit shock in beef production, it has insignificant impact on the exchange rate. The reaction of the interest rate in the face of one unit shock in beef production in first two periods and 5th period is positive, while 6th period negative, and in following periods, reaction was considerably weak. The reaction of the WPI in the face of one unit shock in beef production is positive in 4th period and in other periods insignificant reaction occurred. In response to one unit shock in buffalo meat production, the reaction of beef and mutton production and dollar exchange rate were weak, whereas goat meat production amount in 1st, 2nd, and 6th periods are positive, in following years insignificant; interest rate (\%) in first two periods positive, in following years undulant; WPI (\%) in first three periods negative, in 4th period positive, and in following years reacted weakly. 
While the reaction of the dollar exchange rate and interest rate (\%) in the face of one unit shock in goat meat production amount remains weak, WPI's reaction (\%) in first three periods is negative, 4th and 5th period positive. While the reaction of the dollar exchange rate in the face of one unit shock in mutton production amount remains weak, interest rate in first two periods is positive, later undulant. After 6th period weak reaction, WPI's reaction (\%) in first three periods is negative, 4th and 5th period positive, and in following periods, its reaction remains weak. While one unit shock in dollar exchange rate does not make a significant effect on buffalo and mutton meat production amount, in beef production amount, it has created a positive impact in first two years; in goat meat production amount, it has created a positive impact in first five years. While the effect of interest rate was negative in beef, buffalo meat, and goat meat production in first year, it was positive in mutton. In responses to the shock in interest rate reaction in beef production, it was weak after 5th period and buffalo meat reacted negatively in 1st and 7th periods, positively in others; while goat meat reacted negatively between the $3 \mathrm{rd}$ and 9 th periods and mutton production displayed an undulant reaction. In response to one unit shock in WPI, in goat meat, and in beef and mutton production, insignificant reaction occurred; there was a negative in buffalo meat production and there was a positive effect in 1st year.

According to Özgen and Güloğlu (2004), in the study of "Analysis of Economic Effects of Domestic Debt in Turkey using VAR Technique", causalities between domestic debt and main macroeconomic variables are tested for 1988:12-2003:4 period. According to the impulse response analysis, it shows also that a shock to the domestic debt has negative and significant impact on central bank money.

Table 4

Results of Variance Decomposition Analysis

\begin{tabular}{lllllllll}
\hline \multicolumn{7}{l}{ Variance decomposition: KEE } \\
\hline Period & S.E. & KEE & KOE & ME & SE & DOLAR & INTEREST & WPI \\
\hline 1 & $4,946.104$ & 100.0000 & 0.000000 & 0.000000 & 0.000000 & 0.000000 & 0.000000 & 0.000000 \\
2 & $5,472.180$ & 81.97486 & 0.929761 & 0.076811 & 7.385241 & 0.721974 & 3.542154 & 5.369197 \\
3 & $6,057.819$ & 68.44737 & 2.880245 & 0.396595 & 6.329353 & 6.064027 & 4.008564 & 11.87385 \\
4 & $6,724.924$ & 56.25545 & 4.023432 & 2.772439 & 13.67329 & 6.846130 & 3.612842 & 12.81641 \\
5 & $6,928.435$ & 53.29599 & 3.801470 & 4.578583 & 13.65538 & 6.991193 & 3.424536 & 14.25284 \\
6 & $7,590.448$ & 47.91138 & 3.457343 & 11.09142 & 11.70236 & 7.743573 & 4.726788 & 13.36714 \\
7 & $7,706.356$ & 46.48099 & 3.628975 & 11.08650 & 11.50471 & 7.572912 & 5.847675 & 13.87824 \\
8 & $7,858.524$ & 45.69769 & 3.915655 & 11.45794 & 11.59135 & 8.254904 & 5.718042 & 13.36441 \\
9 & $8,077.039$ & 47.64415 & 3.747689 & 11.22214 & 11.02035 & 8.047847 & 5.666723 & 12.65109 \\
10 & $8,358.938$ & 45.98384 & 3.580738 & 11.23001 & 11.77804 & 9.401555 & 5.734563 & 12.29125 \\
\hline Variance decomposition: KOE & & & & & & \\
\hline Period & S.E. & KEE & KOE & ME & SE & DOLAR & INTEREST & WPI \\
\hline 1 & $14,977.01$ & 44.68096 & 55.31904 & 0.000000 & 0.000000 & 0.000000 & 0.000000 & 0.000000 \\
2 & $19,225.49$ & 27.27066 & 34.33736 & 0.129810 & 4.101814 & 0.562747 & 16.10605 & 17.49156 \\
3 & $23,586.82$ & 31.21691 & 26.38617 & 0.121747 & 5.417112 & 4.836712 & 13.80163 & 18.21971 \\
4 & $29,057.68$ & 26.37983 & 17.40176 & 1.263067 & 14.97489 & 5.679456 & 13.56063 & 20.74036 \\
5 & $30,468.30$ & 30.49504 & 16.08554 & 1.148893 & 13.67763 & 5.584293 & 13.57026 & 19.43834 \\
6 & $33,484.61$ & 28.96183 & 13.37918 & 10.00536 & 11.36930 & 5.428466 & 13.66893 & 17.18693 \\
7 & $34,454.59$ & 27.81447 & 13.37626 & 12.53593 & 10.87080 & 5.959947 & 12.94186 & 16.50072 \\
8 & $34,843.48$ & 28.75916 & 13.09498 & 12.30197 & 10.72577 & 6.287012 & 12.67736 & 16.15375 \\
9 & $35,717.12$ & 31.23952 & 12.47033 & 11.85419 & 10.27711 & 6.178491 & 12.60678 & 15.37358 \\
10 & $36,948.75$ & 30.74833 & 11.85649 & 12.08414 & 11.29037 & 7.123735 & 12.39543 & 14.50150 \\
\hline
\end{tabular}


Table 4 to be continued

\begin{tabular}{|c|c|c|c|c|c|c|c|c|}
\hline \multicolumn{9}{|c|}{ Variance decomposition: ME } \\
\hline Period & S.E. & KEE & KOE & $\mathrm{ME}$ & SE & DOLAR & INTEREST & WPI \\
\hline 1 & $1,156.254$ & 0.137450 & 20.72899 & 79.13356 & 0.000000 & 0.000000 & 0.000000 & 0.000000 \\
\hline 2 & $1,411.970$ & 0.288915 & 14.04892 & 55.77183 & 6.401106 & 0.006939 & 7.539305 & 15.94298 \\
\hline 3 & $1,617.629$ & 0.414336 & 11.52200 & 42.62062 & 5.021625 & 1.059665 & 5.796083 & 33.56567 \\
\hline 4 & $1,796.992$ & 0.807689 & 10.02819 & 35.55361 & 5.073600 & 1.169155 & 6.854543 & 40.51322 \\
\hline 5 & $1,866.576$ & 1.379102 & 9.433499 & 32.98197 & 5.093053 & 1.315797 & 8.756520 & 41.04006 \\
\hline 6 & $2,047.937$ & 4.238617 & 8.035869 & 34.19932 & 6.880538 & 2.817165 & 9.673204 & 34.15529 \\
\hline 7 & $2,127.661$ & 4.387403 & 7.480579 & 37.09148 & 6.381655 & 2.709256 & 9.397163 & 32.55247 \\
\hline 8 & $2,156.805$ & 5.125895 & 7.315303 & 36.66799 & 6.210989 & 3.599779 & 9.145265 & 31.93478 \\
\hline 9 & $2,211.966$ & 8.089540 & 7.634600 & 35.56461 & 5.946720 & 3.581509 & 8.765975 & 30.41705 \\
\hline 10 & $2,271.588$ & 9.523396 & 8.075117 & 33.75584 & 6.123533 & 4.319070 & 9.018998 & 29.18404 \\
\hline \multicolumn{9}{|c|}{ Variance decomposition: SE } \\
\hline Period & S.E. & KEE & KOE & $\mathrm{ME}$ & SE & DOLAR & INTEREST & WPI \\
\hline 1 & $79,551.82$ & 55.74261 & 9.955504 & 4.811172 & 29.49071 & 0.000000 & 0.000000 & 0.000000 \\
\hline 2 & $83,103.88$ & 52.72995 & 9.848385 & 8.827169 & 27.20246 & 0.001183 & 1.111796 & 0.279059 \\
\hline 3 & $90,430.39$ & 44.53623 & 9.995300 & 13.24300 & 22.97461 & 0.100841 & 7.328573 & 1.821445 \\
\hline 4 & $105,081.0$ & 38.65114 & 7.732440 & 9.932308 & 18.58227 & 0.082047 & 10.44090 & 14.57889 \\
\hline 5 & $108,949.1$ & 37.42371 & 8.209064 & 9.328902 & 17.33498 & 0.280120 & 11.26860 & 16.15462 \\
\hline 6 & $116,009.4$ & 36.43620 & 7.302421 & 12.13213 & 15.47953 & 0.271615 & 14.02050 & 14.35761 \\
\hline 7 & $122,111.1$ & 33.29656 & 6.622078 & 19.25900 & 13.98770 & 0.818670 & 13.00198 & 13.01402 \\
\hline 8 & $124,332.8$ & 32.67984 & 6.392100 & 20.83313 & 13.67291 & 1.280578 & 12.54812 & 12.59332 \\
\hline 9 & $127,489.8$ & 34.73615 & 6.157033 & 19.84463 & 13.01577 & 1.364639 & 12.88235 & 11.99942 \\
\hline 10 & $130,867.3$ & 35.31353 & 6.584063 & 18.91155 & 12.84032 & 2.518026 & 12.23603 & 11.59649 \\
\hline \multicolumn{9}{|c|}{ Variance decomposition: DOLAR } \\
\hline Period & S.E. & KEE & KOE & $\mathrm{ME}$ & SE & DOLAR & INTEREST & WPI \\
\hline 1 & $197,622.1$ & 2.597267 & 30.85119 & 0.563166 & 4.389040 & 61.59934 & 0.000000 & 0.000000 \\
\hline 2 & $250,327.3$ & 34.94452 & 20.50816 & 0.924247 & 5.077079 & 38.41054 & 0.135228 & 0.000226 \\
\hline 3 & $252,730.4$ & 34.36103 & 20.12138 & 0.912192 & 5.035377 & 37.68391 & 1.878386 & 0.007727 \\
\hline 4 & $280,244.1$ & 34.76570 & 16.36440 & 0.826699 & 11.86948 & 33.00292 & 1.527661 & 1.643136 \\
\hline 5 & $297,199.5$ & 35.91235 & 14.85999 & 1.500574 & 10.79941 & 29.39474 & 3.781594 & 3.751352 \\
\hline 6 & $323,945.6$ & 36.93118 & 13.16456 & 1.375981 & 9.090880 & 29.88000 & 4.446123 & 5.111276 \\
\hline 7 & $337,704.5$ & 35.66582 & 13.20339 & 1.273665 & 11.00059 & 28.71515 & 5.282805 & 4.858584 \\
\hline 8 & $353,244.2$ & 33.11864 & 12.13755 & 1.164720 & 10.09843 & 27.71222 & 4.886131 & 10.88231 \\
\hline 9 & $365,550.9$ & 32.07322 & 11.33435 & 3.893919 & 9.476471 & 25.87788 & 4.784721 & 12.55944 \\
\hline 10 & $375,637.7$ & 30.82299 & 10.77770 & 4.740352 & 9.127103 & 24.72341 & 7.773419 & 12.03502 \\
\hline \multicolumn{9}{|c|}{ Variance decomposition: FAİZ } \\
\hline Period & S.E. & KEE & $\mathrm{KOE}$ & $\mathrm{ME}$ & SE & DOLAR & INTEREST & WPI \\
\hline 1 & 5.779316 & 3.598181 & 0.579041 & 18.28084 & 2.577052 & 19.68201 & 55.28287 & 0.000000 \\
\hline 2 & 7.751557 & 15.21877 & 0.961802 & 24.01185 & 6.779288 & 14.37759 & 34.54368 & 4.107012 \\
\hline 3 & 7.871475 & 14.75876 & 0.932772 & 23.34310 & 6.617246 & 15.77589 & 33.83134 & 4.740892 \\
\hline 4 & 9.235964 & 20.36327 & 1.070161 & 16.96498 & 4.836259 & 11.47679 & 25.61472 & 19.67382 \\
\hline 5 & 9.767568 & 20.07485 & 1.922178 & 16.20017 & 7.386519 & 11.67708 & 24.64773 & 18.09149 \\
\hline 6 & 9.983228 & 19.83667 & 1.846297 & 17.92502 & 7.161247 & 12.07346 & 23.82513 & 17.33218 \\
\hline 7 & 10.30626 & 21.04449 & 1.787532 & 18.49173 & 7.157581 & 11.34529 & 22.58471 & 17.58867 \\
\hline 8 & 10.74220 & 22.09664 & 1.938142 & 18.58378 & 7.392780 & 10.52653 & 21.02145 & 18.44068 \\
\hline 9 & 10.80758 & 22.30288 & 1.916547 & 18.57965 & 7.323183 & 10.40567 & 20.92431 & 18.54775 \\
\hline 10 & 10.89789 & 21.96160 & 2.635424 & 18.27310 & 7.420868 & 10.55604 & 20.61040 & 18.54257 \\
\hline
\end{tabular}


Table 4 to be continued

\begin{tabular}{lllllllll}
\hline \multicolumn{2}{l}{ Variance decomposition: TEFE } \\
\hline Period & S.E. & KEE & KOE & ME & SE & DOLAR & INTEREST & WPI \\
\hline 1 & 29.44822 & 17.10443 & 0.749470 & 7.846549 & 0.449082 & 18.10753 & 2.524338 & 53.21860 \\
2 & 42.02363 & 22.93048 & 1.083694 & 4.669114 & 6.857945 & 18.43669 & 2.690805 & 43.33128 \\
3 & 47.18968 & 27.30116 & 2.180764 & 3.977086 & 7.198144 & 14.63333 & 4.627777 & 40.08174 \\
4 & 48.79816 & 25.53130 & 2.096142 & 8.639097 & 7.173411 & 14.01121 & 4.439623 & 38.10922 \\
5 & 50.78562 & 23.85511 & 1.985520 & 12.60133 & 6.758222 & 13.17063 & 4.771410 & 36.85778 \\
6 & 51.83495 & 23.97038 & 2.043189 & 12.26555 & 6.488528 & 12.83739 & 5.564524 & 36.83043 \\
7 & 52.37580 & 24.00738 & 2.754894 & 12.27171 & 6.818954 & 12.62108 & 5.450195 & 36.07579 \\
8 & 53.87298 & 24.85497 & 2.774370 & 12.18537 & 7.035439 & 12.03412 & 5.278382 & 35.83736 \\
9 & 54.37977 & 24.64031 & 2.788327 & 12.02945 & 7.226350 & 11.85519 & 5.363225 & 36.09715 \\
10 & 54.59395 & 24.71265 & 2.797727 & 11.94864 & 7.623739 & 11.76489 & 5.327124 & 35.82524 \\
\hline
\end{tabular}

According to the results of variance decomposition analysis given in Table 4, the goat meat production describes the values for the next period $100 \%$; after two periods, it can describe $81.97 \%$; after three periods, $68.45 \%$; and after 10 periods $45.98 \%$. For the same period of goat meat production, after 10 periods, it was able to describe mutton production $3.58 \%$, buffalo meat $11.23 \%$, beef $11.78 \%$, dollar exchange rate $9.40 \%$, interest rate $5.73 \%$, and WPI $12.29 \%$. When the change in the variance of mutton production amount studied, at the end of 10 periods, explanatory rates belong to respectively with $30.75 \%$ to mutton production amount, with $14.50 \%$ to WPI, with $12.40 \%$ interest rate, with $12.08 \%$ to buffalo meat production amount, with $11.86 \%$ to variable itself, with $11.29 \%$ to beef production amount, and with $7.12 \%$ dollar exchange rate. Explanatory rates of change in variance of buffalo meat production amount respectively with $33.76 \%$ belong to variable itself, with $29.18 \%$ to WPI, with $9.52 \%$ to mutton production amount, with $9.02 \%$ interest rate, with $8.08 \%$ to mutton production amount, with $6.12 \%$ beef production amount, and with $4.32 \%$ to dollar exchange rate. Explanatory rates of change in variance of beef production amount respectively with $35.31 \%$ belong to goat meat production amount, with $18.91 \%$ to buffalo meat production amount, with $12.84 \%$ to itself, with $12.24 \%$ to interest rate, with $11.60 \%$ to WPI, with $6.59 \%$ to mutton production amount, and with $2.52 \%$ to dollar exchange rate. Explanatory rates of change in variance of dollar exchange rate respectively with $30.82 \%$ belong to goat meat production amount, with $24.72 \%$ to itself, with $12.04 \%$ to WPI, with $10.78 \%$ to mutton production amount, with $9.13 \%$ to beef production amount, with $7.77 \%$ to interest rate, and with $4.74 \%$ to buffalo meat production amount. Explanatory rates of change in variance of interest rates respectively with $21.96 \%$ belong to goat meat production amount, with $20.61 \%$ to itself, with $18.54 \%$ to WPI, with $10.56 \%$ to dollar exchange rate, with $18.27 \%$ to buffalo meat production amount, with $7.42 \%$ to beef production amount, and with $2.64 \%$ to mutton production amount. Explanatory rates of change in variance of WPI respectively with $35.83 \%$ belong to variable itself, with $24.71 \%$ to goat meat production amount, with $11.95 \%$ to buffalo meat production amount, with $11.76 \%$ dollar exchange rate, with $7.62 \%$ beef production amount, with $5.33 \%$ interest rate, and with $2.80 \%$ to mutton production amount.

\section{Conclusions}

In this study, the factors affecting the red meat production in Turkey were detected with VAR analysis. In this analysis, beef, buffalo meat, mutton, goat meat production amounts, dollar exchange rate, inflation rate according to consumer price index (WPI), and interest rate are used as variables. As outcome of VAR analysis 
was obtained with Granger causality test, variance decomposition and impulse response analysis interpreted in three forms. According to these results, dollar exchange rate, WPI, and interest rate have impacts on red meat production of Turkey.

In result of variance decomposition, the biggest effect of goat meat production on the variables is its own lagged values. Similarly, the biggest effect of WPI values on the variables is its own lagged values. The biggest effect of mutton production amount on the variables is goat meat production amount. Similarly, the biggest effect of beef, dollar, and interest values on the variables is goat meat production amount.

Again in the result of variance decomposition, dollar exchange rate affected goat meat production amount by $30.82 \%$, mutton production amount by $10.78 \%$, beef production amount by $9.13 \%$, and buffalo meat production amount by $4.74 \%$. WPI affected goat meat production amount by $24.71 \%$, buffalo meat production amount by $11.95 \%$, beef production amount by $7.62 \%$, and mutton production amount by $2.80 \%$. INTEREST rate affected goat meat production amount by $21.96 \%$, buffalo meat production amount by $18.27 \%$, beef production amount by $7.42 \%$, and mutton production amount by $2.64 \%$. In accordance with these results, dollar exchange rate, WPI, and interest rate have the most effect on goat meat production amount. The least affected by dollar exchange rate are buffalo meat production amount, WPI and the least affected by interest rate are mutton production amount.

In Granger causality analysis between the variables of goat meat production amount and dollar exchange rate, a one-way association was revealed from goat meat production to dollar rate. Impulse response functions and variance decomposition also supported these results.

According to the results obtained, it has revealed that, in general, the red meat production amount, dollar exchange rate, WPI, and interest rate affect the goat meat production amount the most.

\section{References}

Anonymous. (2015). Wholesale price index. Retrieved from http://www.alomaliye.com/2015/tufe-aralik-2014.htm

Akdi, Y. (2010). Time series analysis (unit roots vs. cointegration). Ankara: Gazi Bookstore.

Akkaya, M. (2015). TRA2 (Turkey level II region: A $\breve{g r l}$, Ardahan, I $\breve{g} d ı r$, and Kars) area red meat sector strategic analysis. Kars: Serhat Development Agency.

Albayrak, K. (2002). Meat and livestock trafficking in Turkey (Unpublished report, Ankara).

Asteriou, D., \& Hall, S. (2007). Applied econometrics: A modern approach using eviews and microfit revisited edition. New York: Palgrave Macmillan.

Berber, M., \& Artan, S. (2004). Inflation and economic growth relationship in Turkey: Theory, literature and practice. Journal of Atatürk University Faculty of Economics and Administrative Sciences, 18(3-4), 1-17.

Darnell, A. C. (1994). A dictionary of econometrics. Cornwall: Hartnolls Limited.

Dickey, D. A., \& Fuller, W. A. (1981). Likelihood ratio statistics for autoregressive time series with a unit root. Econometrica, 49(4), 1057-1072.

Enders, W. (1995). Applied econometric time series. New York: John Wiles and Sons.

Engle, R. F., Gallo, G. M., \& Velucchi, M. (2012). A MEM-based analysis of volatility spillovers in East Asian financial markets. The Review of Economics and Statistics, 94(1), 222-223.

Granger, C. W. J., \& Newbold, P. (1986). Forecasting economic time series, economic theory. Econometrics and mathematical economics (2nd ed.). New York: Harcourt Brace Jovanovich.

Granger, C. W. J. (1969). Investigating causal relations by econometric models and cross-spectral methods. Econometrica, 37 , 24-36.

Granger, C. W. J. (1980). Some comments on the role of time series analysis in econometrics. New York: Ramsey Academic Press.

Greene, W. H. (1993). Econometric analysis. Upper Saddle River: Prentice-Hall Publication. 
Günaydın, G. (2006). Turkey agricultural sector. Agriculture and Engineering, 3, 17.

Kadilar, C. (2000). Applied multivariate time series analysis. Ankara: Bizim Office Press.

Kalkınma Bakanlığı. (2010). Retrieved from http://www.kalkinma.gov.tr/Pages/EkonomikSosyalGostergeler.aspx

Keating, J. W. (1990). Identifying VAR models under rational expectations. Journal of Monetary Economics, 25, 453-476.

Kumar, V., Robert, P. L., \& John, N. G. (1995). Aggregate and disaggregate sector forecasting using consumer confidence measures. International Journal of Forecasting Elsevier, 11(3), 361-377.

Maddala, G. S. (1989). Introduction to econometrics. New York: Macmillan publishing Company.

Nazlığlu, Ş. (2010). Impacts of macro economic policies on agricultural sector: A comparison for developed and developing countries (Ph.D. thesis, Erciyes University, Institute of Social Sciences, Kayseri, p. 173).

Nieh, C., \& Yau, H. (2004). Time series analysis for the interest rates relationships among China, Hong Kong, and Taiwan money markets. Journal of Asian Economics, 15(1), 171-188.

Okumuş, M. (2012). Agricultural policy and time series analysis: An application on cotton price in Turkey (Adnan Menderes University, Institute of Science, Aydın).

Olhan, E. (2006). Investigation of the agricultural sector in the EU and Turkey. Retrieved from http://player.slideplayer.biz.tr/9/2610549/\#

Özgen, F. B., \& Güloğlu, B. (2004). Analysis of economic effects of domestic debt in Turkey using VAR technique. METU Studies in Development, 31, 93-114.

Pindyck, R. S., \& Rubinfeld, D. L. (1991). Econometric models and economic forecasts. New York: McGraw-Hill.

Shumway, R. H., \& Stoffer, D. S. (2006). Time series analysis and its applications with R examples. New York: Springer Texts in Statistics.

Sims, C. A. (1972). Money, 1ncome, and causality. The American Economic Review, 62(4), 540-552.

Sims, C. A. (1980). Macroeconometrics and reality. Econometrica, 48(1), 1-48.

State Planning Organization. (2007). Ninth development plan 2007-2013 (Food industry, special commission report, p. 45).

Stock, J. H., \& Watson, M. W. (2001). Vector autoregressions. Journal of Economic Perspectives, 15(4), 101-115.

Subaş1, O. S., \& Ören, M. C. (2013). Agricultural R\&D spending growth and agricultural relations in Turkey. Akdeniz University Faculty of Agriculture Journal, 26(2), 99-104.

Tarı, R. (2014). Econometrics (Umuttepe publications, publication number 32, Kocaeli University).

TCMB. (2015). The indicative exchange rate of the central bank. Retrieved from http://www.tcmb.gov.tr/wps/wcm/connect/TCMB+TR/TCMB+TR/Main+Menu/Istatistikler/Doviz+Kurlari/Gosterge+Nitelig indeki+Merkez+Bankasi+Kurlarii

The United Nations Food and Agriculture Organization. (2013). Food and agriculture organization of the United States. Retrieved from http://faostat3.fao.org/download/Q/QA/E

Statistical Institute of Turkey [TÜİK]. (2014). Türkiye İstatistik Kurumu Haber Bülteni (Sayı: 18851, 13 Şubat 2015, Ankara).

Ünlüsoy, K., İnce, E., \& Güler, F. (2010). Red meat sector and competition policy in Turkey (Head of Department the Competition Authority, Ankara). 
Annex. VAR Analysis Results

\begin{tabular}{|c|c|c|c|c|c|c|c|}
\hline & KEE & KOE & $\mathrm{ME}$ & SE & DOLAR & INTEREST & WPI \\
\hline \multirow{3}{*}{ KEE(-1) } & -0.135149 & -9.6455 & -0.030778 & -1.011998 & 17.22337 & 0.000325 & -0.001180 \\
\hline & $(0.32129)$ & (77.5755) & $(0.07344)$ & $(5.32190)$ & $(17.9176)$ & $(0.00061)$ & $(0.00246)$ \\
\hline & {$[-0.42064]$} & {$[-0.12434]$} & {$[-0.41909]$} & {$[-0.19016]$} & {$[0.96125]$} & {$[0.53351]$} & {$[-0.48015]$} \\
\hline \multirow{3}{*}{$\operatorname{KEE}(-2)$} & -0.680737 & -52.8564 & -0.160914 & -6.371924 & 7.312547 & $2.22 \mathrm{E}-06$ & -0.000502 \\
\hline & $(0.23190)$ & $(55.9921)$ & $(0.05301)$ & $(3.84122)$ & $(12.9325)$ & $(0.00044)$ & $(0.00177)$ \\
\hline & {$[-2.93546]^{*}$} & {$[-0.94400]$} & {$[-3.0356]^{* *}$} & {$[-1.65883]$} & {$[0.56544]$} & {$[0.00506]$} & {$[-0.28278]$} \\
\hline \multirow{3}{*}{$\operatorname{KEE}(-3)$} & 0.138275 & -97.013 & 0.055547 & 12.52165 & 21.96015 & 0.000141 & -0.001587 \\
\hline & $(0.34849)$ & (84.1433) & $(0.07966)$ & $(5.77247)$ & $(19.4346)$ & $(0.00066)$ & $(0.00267)$ \\
\hline & {$[0.39678]$} & {$[-1.15295]$} & {$[0.69730]$} & {$[2.16920]^{*}$} & [ 1.12995$]$ & {$[0.21331]$} & {$[-0.59550]$} \\
\hline \multirow{3}{*}{$\mathrm{KOE}(-1)$} & 0.001659 & 0.005503 & 0.000435 & 0.028876 & -0.016149 & $-4.56 \mathrm{E}-07$ & $1.20 \mathrm{E}-06$ \\
\hline & $(0.00109)$ & $(0.26315)$ & $(0.00025)$ & $(0.01805)$ & $(0.06078)$ & $(2.1 \mathrm{E}-06)$ & $(8.3 \mathrm{E}-06)$ \\
\hline & [ 1.52193$]$ & {$[0.02091]$} & [ 1.74565$]$ & [ 1.59951$]$ & {$[-0.26570]$} & {$[-0.22101]$} & [ 0.14402$]$ \\
\hline \multirow{3}{*}{$\mathrm{KOE}(-2)$} & -0.000393 & 0.041322 & $2.31 \mathrm{E}-05$ & -0.007127 & -0.005345 & $-9.42 \mathrm{E}-08$ & $7.02 \mathrm{E}-06$ \\
\hline & $(0.00066)$ & $(0.15862)$ & $(0.00015)$ & $(0.01088)$ & $(0.03664)$ & $(1.2 \mathrm{E}-06)$ & $(5.0 \mathrm{E}-06)$ \\
\hline & {$[-0.59794]$} & {$[0.26051]$} & {$[0.15365]$} & {$[-0.65497]$} & {$[-0.1459]$} & {$[-0.07574]$} & [ 1.39715$]$ \\
\hline \multirow{3}{*}{$\mathrm{KOE}(-3)$} & 0.000436 & 0.059545 & -0.000123 & -0.012750 & 0.008186 & $6.22 \mathrm{E}-07$ & $4.40 \mathrm{E}-07$ \\
\hline & $(0.00073)$ & $(0.17646)$ & $(0.00017)$ & $(0.01211)$ & $(0.04076)$ & $(1.4 \mathrm{E}-06)$ & $(5.6 \mathrm{E}-06)$ \\
\hline & {$[0.59683]$} & {$[0.33743]$} & {$[-0.73603]$} & {$[-1.05318]$} & {$[0.20084]$} & [ 0.44907$]$ & {$[0.07868]$} \\
\hline \multirow{3}{*}{$\operatorname{ME}(-1)$} & 3.139368 & 292.6168 & 0.601531 & 40.75014 & -76.896 & 0.000530 & -0.004486 \\
\hline & $(1.29373)$ & $(312.368)$ & $(0.29572)$ & (21.4294) & $(72.1477)$ & $(0.00245)$ & $(0.00989)$ \\
\hline & {$[2.42660]^{*}$} & [ 0.93677$]$ & [2.03409]* & [ 1.90160$]$ & {$[-1.06581]$} & {$[0.21623]$} & {$[-0.45341]$} \\
\hline \multirow{3}{*}{$\operatorname{ME}(-2)$} & -0.902931 & 480.8328 & 0.052931 & -7.145978 & 16.19887 & -0.001286 & 0.007571 \\
\hline & $(1.00422)$ & $(242.466)$ & $(0.22955)$ & (16.6339) & $(56.0024)$ & $(0.00190)$ & $(0.00768)$ \\
\hline & {$[-0.89914]$} & [ 1.98309] & [0.23059] & {$[-0.42960]$} & {$[0.28925]$} & {$[-0.67600]$} & [ 0.98578$]$ \\
\hline \multirow{3}{*}{$\operatorname{ME}(-3)$} & -1.337609 & -451.337 & -0.434131 & -24.196 & 27.33380 & -0.000106 & -0.009282 \\
\hline & $(1.09550)$ & $(264.506)$ & $(0.25041)$ & (18.1458) & (61.0929) & $(0.00207)$ & $(0.00838)$ \\
\hline & {$[-1.22101]$} & {$[-1.70634]$} & {$[-1.73367]$} & {$[-1.33343]$} & {$[0.44741]$} & {$[-0.05126]$} & {$[-1.10787]$} \\
\hline \multirow{3}{*}{$\mathrm{SE}(-1)$} & -0.023116 & 6.164117 & -0.007002 & -0.261669 & 1.275358 & $5.81 \mathrm{E}-07$ & $7.86 \mathrm{E}-05$ \\
\hline & $(0.01905)$ & $(4.60047)$ & $(0.00436)$ & $(0.31561)$ & $(1.06257)$ & $(3.6 \mathrm{E}-05)$ & $(0.00015)$ \\
\hline & {$[-1.21319]$} & [ 1.33989$]$ & {$[-1.60765]$} & {$[-0.82910]$} & [ 1.20026$]$ & [ 0.01611$]$ & [ 0.53944$]$ \\
\hline \multirow{3}{*}{$\operatorname{SE}(-2)$} & 0.011007 & 9.313538 & 0.001957 & 0.364508 & -0.489556 & $2.01 \mathrm{E}-05$ & -0.000119 \\
\hline & $(0.02044)$ & $(4.93612)$ & $(0.00467)$ & $(0.33863)$ & $(1.14010)$ & (3.9E-05) & $(0.00016)$ \\
\hline & {$[0.53842]$} & [ 1.88681$]$ & {$[0.41878]$} & [ 1.07641$]$ & {$[-0.42940]$} & [ 0.51931$]$ & {$[-0.76298]$} \\
\hline \multirow{3}{*}{$\operatorname{SE}(-3)$} & 0.013385 & 13.85163 & -0.001648 & -0.237293 & -0.561202 & $-1.13 \mathrm{E}-05$ & $7.38 \mathrm{E}-05$ \\
\hline & $(0.02137)$ & $(5.16059)$ & $(0.00489)$ & $(0.35403)$ & (1.19194) & $(4.0 \mathrm{E}-05)$ & $(0.00016)$ \\
\hline & {$[0.62624]$} & {$[2.6841]^{* *}$} & {$[-0.33737]$} & {$[-0.67026]$} & {$[-0.47083]$} & {$[-0.27902]$} & [ 0.45158$]$ \\
\hline \multirow{5}{*}{ DOLAR(-1) } & 0.009637 & 0.507841 & 0.002488 & 0.098670 & -0.072337 & $-5.46 \mathrm{E}-06$ & $-1.59 \mathrm{E}-05$ \\
\hline & $(0.00605)$ & $(1.46042)$ & $(0.00138)$ & $(0.10019)$ & $(0.33731)$ & $(1.1 \mathrm{E}-05)$ & $(4.6 \mathrm{E}-05)$ \\
\hline & [ 1.59326$]$ & [ 0.34774$]$ & [ 1.79945$]$ & [ 0.98484$]$ & {$[-0.21445]$} & {$[-0.47666]$} & {$[-0.34312]$} \\
\hline & $(0.00606)$ & $(1.46288)$ & $(0.00138)$ & $(0.10036)$ & $(0.33788)$ & $(1.1 \mathrm{E}-05)$ & $(4.6 \mathrm{E}-05)$ \\
\hline & {$[-0.72308]$} & [1.68062] & {$[0.85333]$} & [ 0.54943$]$ & {$[-0.08225]$} & {$[-0.06468]$} & {$[-0.07307]$} \\
\hline \multirow{3}{*}{ DOLAR(-2) } & -0.00438 & 2.4585 & 0.001182 & 0.055139 & -0.027789 & $-7.42 \mathrm{E}-07$ & $-3.39 \mathrm{E}-06$ \\
\hline & $(0.00606)$ & $(1.46288)$ & $(0.00138)$ & $(0.10036)$ & $(0.33788)$ & $(1.1 \mathrm{E}-05)$ & $(4.6 \mathrm{E}-05)$ \\
\hline & {$[-0.72308]$} & [1.68062] & {$[0.85333]$} & [ 0.54943$]$ & {$[-0.08225]$} & {$[-0.06468]$} & {$[-0.07307]$} \\
\hline \multirow{3}{*}{ DOLAR(-3) } & -0.016178 & -1.3788 & -0.004810 & -0.231338 & 0.311239 & $-1.59 \mathrm{E}-05$ & $-7.01 \mathrm{E}-05$ \\
\hline & $(0.00811)$ & $(1.95752)$ & $(0.00185)$ & $(0.13429)$ & $(0.45213)$ & $(1.5 \mathrm{E}-05)$ & $(6.2 \mathrm{E}-05)$ \\
\hline & {$[-1.99540]$} & {$[-0.70436]$} & {$[-2.59535]^{*}$} & {$[-1.72265]$} & {$[0.68839]$} & {$[-1.03345]$} & [-1.13015] \\
\hline
\end{tabular}


To be continued

\begin{tabular}{|c|c|c|c|c|c|c|c|}
\hline & KEE & $\mathrm{KOE}$ & $\mathrm{ME}$ & $\mathrm{SE}$ & DOLAR & INTEREST & WPI \\
\hline \multirow{3}{*}{ FAİZ(-1) } & 207.2362 & -66498.61 & 50.82876 & $-5,786.678$ & -3.703 .457 & 0.175153 & 0.316692 \\
\hline & (201.879) & $(48743.3)$ & $(46.1461)$ & $(3,343.93)$ & $(11258.2)$ & $(0.38229)$ & $(1.54392)$ \\
\hline & {$[1.02654]$} & {$[-1.36426]$} & [1.10148] & {$[-0.17305]$} & {$[-0.32896]$} & {$[0.45816]$} & {$[0.20512]$} \\
\hline \multirow{3}{*}{ FAİZ(-2) } & $-2,159.242$ & $-53,097.09$ & $-2,992.078$ & $-6,226.787$ & $7,536.469$ & -0.278928 & -0.607095 \\
\hline & $(212.634)$ & $(51,340.0)$ & (48.6044) & $(3,522.07)$ & $(11,858.0)$ & $(0.40266)$ & $(1.62617)$ \\
\hline & {$[-1.01547]$} & {$[-1.03422]$} & {$[-0.61560]$} & {$[-1.76793]$} & {$[0.63556]$} & {$[-0.69271]$} & {$[-0.37333]$} \\
\hline \multirow{3}{*}{ FAİZ(-3) } & 10.36602 & $-6,578.078$ & -35.447 & $-1,432.676$ & 3259.091 & 0.153072 & 0.915510 \\
\hline & $(165.712)$ & $(40,010.9)$ & $(37.879)$ & $(2,744.86)$ & $(9241.32)$ & $(0.31381)$ & (1.26733) \\
\hline & {$[0.06255]$} & {$[-0.16441]$} & {$[-0.9358]$} & {$[-0.52195]$} & {$[0.35266]$} & {$[0.48779]$} & [0.72239] \\
\hline \multirow{3}{*}{ TEFE(-1) } & -98.43571 & 292.1181 & -27.455 & -435.318 & 375.1067 & -0.035306 & -0.703282 \\
\hline & $(56.1268)$ & $(13,551.7)$ & (12.8296) & (929.686) & $(3130.04)$ & $(0.10629)$ & $(0.42924)$ \\
\hline & {$[-1.75381]$} & {$[0.02156]$} & {$[-2.13997]^{*}$} & {$[-0.46824]$} & {$[0.11984]$} & {$[-0.33218]$} & {$[-1.63842]$} \\
\hline \multirow{3}{*}{ TEFE(-2) } & -6.153 .174 & -5.481 .736 & -38.78405 & 293.4470 & $-1,951.128$ & -0.043974 & -0.422091 \\
\hline & $(61.3383)$ & $(14,810.0)$ & (14.0209) & (1016.01) & $(3,420.66)$ & $(0.11615)$ & $(0.46910)$ \\
\hline & {$[-1.00315]$} & {$[-0.37014]$} & {$[-2.7662]^{* *}$} & [ 0.28882$]$ & {$[-0.57039]$} & {$[-0.37858]$} & {$[-0.89979]$} \\
\hline \multirow{3}{*}{ TEFE(-3) } & 66.85871 & $-6,299.963$ & 21.92139 & 2440.685 & $-3,204.073$ & 0.100099 & 0.023836 \\
\hline & $(58.6121)$ & $(14,151.8)$ & (13.3977) & $(970.852)$ & $(3,268.64)$ & (0.11099) & $(0.44825)$ \\
\hline & {$[1.14070]$} & {$[-0.44517]$} & {$[1.63620]$} & {$[2.51396]^{*}$} & {$[-0.98025]$} & {$[0.90186]$} & {$[0.05317]$} \\
\hline \multirow{3}{*}{$C$} & $1,911.798$ & $-1,008,900$ & -149.3378 & $27,838.12$ & $48,406.44$ & 0.033834 & 5.700322 \\
\hline & $(1,944.63)$ & $(469,527)$ & (444.509) & $(32,210.9)$ & $(108,447)$ & $(3.68250)$ & $(14.8721)$ \\
\hline & {$[0.98312]$} & {$[-2.14876]$} & {$[-0.33596]$} & {$[0.86425]$} & {$[0.44636]$} & [0.00919] & [0.38329] \\
\hline $\begin{array}{l}R^{2}: \text { Coefficient of } \\
\text { determination }\end{array}$ & 0.747922 & 0.870058 & 0.816600 & 0.737443 & 0.539007 & 0.472373 & 0.638488 \\
\hline$F$-statistics & 1.130293 & 2.550763 & 1.696218 & 1.069977 & 0.445421 & 0.341058 & 0.672824 \\
\hline
\end{tabular}

